\title{
An Evaluation of the Impact of Monetary Policy on the Real Sector in Nigeria
}

\author{
Dr. Gimba Victor Kyari \\ Department of Economics, Kaduna State University, Kaduna, Nigeria \\ gimba1974@yahoo.com
}

\author{
Doi:10.5901/mjss.2015.v6n2p361
}

\begin{abstract}
The objective of the study is to assess the effect monetary policy variables on savings, national income and investment as proxies to the real sector economy in Nigeria. This is relevant to the economy as differences in transmission mechanisms can generate asymmetric behaviour between monetary policy and real sector. The paper explores the significance of this channel using VAR model, as tests suggest the null hypothesis of no significant effect was rejected and a conclusion was drawn that one of the monetary variables such as money supply exert a significant impact on the real sector economy. The main implication to be drawn from these results seems to be the importance of monetary policy channel in regulating real sector economy in Nigeria. The effect of money supply shocks on real sector variables are similar and seem to be significant too. Thus with respect to this result, monetary policy regulators should use money supply regularly as a mechanism to improve real sector economy in Nigeria.
\end{abstract}

Keywords: Monetary Policy, Real Sector, VAR, Transmission Mechanism

\section{Introduction}

A successful implementation of monetary policy requires an accurate assessment of how fast the effects of policy changes propagate to other parts of the economy and how large these effects are. This requires a thorough understanding of the mechanism through which monetary policy affects economic activity. The process that describes how changes in monetary policy propagate to other parts of the economy is called the transmission mechanism of monetary policy. It describes how changes in policy transmit through the financial system, via financial prices and quantities, to the real economy, affecting aggregate spending decisions of households and firms, and from there to aggregate demand and inflation. Given the paramount importance of the transmission mechanism for the understanding of monetary policy, it is surprising that, until very recently, relatively little effort has been invested in understanding exactly how the transmission mechanism works. In the words of Bernanke and Gertler (1995):

The same research that has established that changes in monetary policy are eventually followed by changes in output is largely silent about what happens in the interim. To a great extent, empirical analysis of the effects of monetary policy has treated the monetary transmission mechanism itself as a 'black box.

The transmission mechanism logically involves two stages. The first stage involves the propagation of changes in monetary policy through the financial system. This stage of the transmission mechanism explains how changes in the market operations of Central Banks transmit through the money market to markets which directly affect spending decisions of individuals and firms, that is, the capital and bond market and the bank loan market. This involves the term structure, through which short term money market rates affect longer-term bond rates, and the marginal cost of loan funding, through which bank loan rates are affected. The second stage of the transmission mechanism involves the propagation of monetary policy shocks from the financial system to the real economy. This explains how monetary policy shocks affect real production and aggregate prices. It seems obvious that in order to fully understand the transmission from Central Bank actions to the real economy, the first stage needs to be fully understood. Because of the impact monetary policy has on financing conditions in the economy (not just the costs, but also the availability of credit or banks' willingness to assume specific risks) but also because of its influence on expectations about economic activity and inflation, monetary policy can affect the prices of goods, asset prices, exchange rates as well as consumption and investment.

Interest rate cuts, for example, lower the cost of borrowing, which results in higher investment activities and the purchase of consumer durables. The expectation that economic activity will strengthen may also prompt banks to ease lending policy, which in turn enables businesses and households to boost spending. In a low interest-rate environment, shares become a more attractive buy, raising households' financial assets. This may also contribute to higher consumer 
spending, and makes companies' investment projects more attractive. Lower interest rates also tend to cause currencies to depreciate: Demand for domestic goods rises when imported goods become more expensive. All of these factors raise output and employment as well as investment and consumer spending. However, this stepped-up demand may cause prices and wages to rise if goods and labour markets are fully utilized. Against this background, the paper seeks to evaluates the impact of monetary policy variables on real sector. In order to achieve the objective of this study, the question guided the study is; what is the effect of monetary policy variables on national savings, income and investment? The following postulations were put forward for testing; Monetary policy variables have no significant impact on the real sector variables.

The study therefore, is divided into five sections, the first section being the introduction; the second section deal with review of relevant literature; the third section deals with research methodology employed; the forth section deals with the results and discussion; while the last section pinpoints policy directions for various relevant policy formulators.

\section{Review of Relevant Literature}

Empirical research on the monetary policy channel operating through the cost of capital provided conflicting results. Most existing empirical studies use a standard Vector Auto Regression (VAR) methodology, and as a result the literature lacks a panel data-based approach and gives conflicting results on the transmission channels of monetary policy in emerging market economies. Neaime (2008) for example concludes that the traditional Keynesian interest rate channel dominates the transmission mechanism of monetary policy in Morocco and Tunisia, and that the direct linkages between the interest rate and inflation rates are highly significant.

Boughrara (2009) finds that the credit channel is stronger than the traditional interest rate channel in Tunisia, and that neither the exchange rate channel nor the asset price channel are operative in either Tunisia or Morocco. By contrast Jardak and Wrobel (2009) conclude that the exchange rate channel is the most important in the Tunisian economy. Mishra et al. (2010) argue that for low income countries the strength and reliability of the monetary transmission mechanism depend critically on the effectiveness of the bank lending channel in the presence of limited financial development. Also, they argue that the bank lending channel will operate quite differently in low income countries from what we observe in industrial and emerging economies because of the limited degree of financial development in many low income countries. They primarily compare the correlation between changes in money market rate and lending rates in advanced, emerging and low income countries, and find the correlation coefficient to be weaker for the low income countries relative to advanced and emerging market economies. They explain the weaker coefficient in low income countries in terms of the institutional deficiencies that discourage bank lending activity.

There is a large body of empirical literature on the impact of interest rates on private consumption in advanced economies, but there are relatively few cross-country studies for emerging market economies. Fry (1978) estimates a (national) savings function for seven Asian countries for the period 1962-72 and finds strong support for the hypothesis of a negative and statistically significant real interest rate elasticity of domestic consumption. He estimates this elasticity to be about -0.2 . Similar conclusions are reached by McDonald (1983). McDonald focuses on factors determining savings behavior in 12 Latin American countries and finds evidence of a statistically significant negative relationship between the real interest rate and private consumption in most of the countries examined, with estimated elasticities roughly comparable with that found by Fry (1978). However, he does not find any significant relationship between consumption and the real interest rate. Ross (1995) argues that in low-income developing countries that are characterized by pervasive liquidity constraints, consumption growth is more likely to follow income growth than changes in expected rates of return. Reinhart and Ostry (1995) describe that for a large number of developing countries, there does not appear to be any systematic relationship between rates of return and private consumption behavior due to the poor quality of data in general and the fact that there is considerable variation in the economic significance and informational content of available data on real rates of return. They also argue that the lack of sophistication and depth in financial markets or direct regulation may result in interest rates that do not adequately reflect expectations about underlying economic fundamentals. Using a panel of 16 emerging markets Funke (2002) finds a small but statistically significant effect of stock market developments on private consumption.

More empirical work has been done to assess the impact of the real interest rate on private investment in emerging market economies. Sundararajan and Thakur (1980), TunWai and Wong (1982), and Blejer and Khan (1984) address the analytical and data problems involved in its application to developing countries, in particular the lack of data and the resource constraints facing private investors in developing countries. Regarding the determinants of private investment, the neoclassical model suggests that a rise in the real interest rate raises the cost of borrowing, thereby reducing the private investment. Further, a flexible accelerator model of investment suggests that private investment should be 
positively related to expected future real GDP growth. Greene and Villanueva (1991) estimate the investment function for 23 developing economies from 1975-87 and find that the real interest has a significantly negative effect on private investment. They find that a one percentage point rise in the real interest rate reduces the private investment by 0.1 percentage point. Serven (2003) also finds that private investment in less developed countries responds significantly to interest rate changes. Using a panel data approach, Aysan et. al. (2005) find that the real interest rate had a negative impact on firms' investment projects in five countries (Egypt, Iran, Jordan, Morocco and Tunisia) throughout the 1980s and 1990s, while Bader and Malawi (2010) provide evidence of a significant negative impact of the real interest rate on private investment in Jordan between 1990 and 2005. Turning to Africa, Misati and Nyamongo (2010) also find a significant and negative relationship between the interest rate on deposits and private investment for 18 African countries over the period 1991-2004. However, they do not find any impact of stock market turnover on private investment. Misati (2007) examines the effect of stock market development on investment efficiency in Africa and finds that stock market development matters for investment efficiency in countries in Africa with relatively developed stock markets; however, no consistent results are obtained for countries with relatively underdeveloped stock markets such as Nigeria. The study concludes that African stock markets can boost investment efficiency by enhancing privatization and diversifying financial instruments.

Several studies have argued that capital account openness is an important determinant of investment decisions in emerging market economies. With closed capital markets investment only takes place up to the point where domestic savings equal domestic investment at a given rate of interest. With liberalization of capital account, resources should flow-at least in theory-from capital-abundant developed countries (where the return to capital is low) to capital-scarce developing countries (where the return to capital is high). The flow of resources to developing and emerging market economies reduces their cost of capital, triggering a temporary increase in investment (Fischer (1998, 2003), Obstfeld (1998), Rogoff (1999), Summers (2000).

Existing empirical studies find contradictory results on the effect of financial liberalization on private investment in low income and emerging market economies. Henry (2000) examines the relationship between stock market liberalization and the growth of real private investment using an event study approach in 11 low income and emerging market economies. His study suggests that, on average, these economies experienced a large but temporary increase in the growth rate of real private investment on the heels of stock market liberalization. Henry (2000) also argues that stock market liberalization decreases the cost of equity capital and thereby boosts private investment. Achy (2003) finds a significant negative impact of financial liberalization on private investment for five African countries over the period 19701998. He argues that, by distorting private credit allocation in favor of households at the expense of firms, financial liberalization has tended to reduce available loans for the business sector, and in particular for small and medium-sized enterprises. Naceur, Samir and Omran (2008) by contrast fail to find any significant impact of stock market liberalization on investment growth using annual data for 11 countries over the period 1979-2005. The of the recent study by Mukherjee et al (2011) examine the operation of the traditional Keynesian interest rate channel of the monetary policy transmission mechanism in five potential inflation targeting economies in the emerging economies and compare it with fourteen inflation targeting emerging market economies using panel data analysis. Contrary to some existing studies, their empirical results suggest that private consumption and investment in both groups of countries are sensitive to movements in real interest rates. Furthermore, their study finds that the adoption of inflation targeting did not significantly alter the operation of the interest rate channel in inflation targeting emerging economies.

\section{Research Methodology}

This study uses a VAR modelling framework to capture the dynamics of the relationship between monetary policy variables and real sector. However, it differs from previous Granger causality literature in investigating the monetary policy-real sector with impulse response function and variance decomposition to investigate causality. Enders (1995) proposed that forecast error variance decomposition permits inferences to be drawn regarding the proportion of the movement in a particular time-series due to its own earlier "shocks" vis-à-vis "shocks" arising from other variables in the VAR. After estimating the VAR, the impact of a "shock" in a particular variable is traced through the system of equations to determine the effect on all of the variables, including future values of the "shocked" variable.

\subsection{Model Specification}

The study considered eight variables in all. Saving income and investment are proxies for real sector. Linear regression models are specified for all the real sector (RS) and monetary policy (MP) variables. Savings (SV), income (IN), 
investment (INV), functions of monetary policy variables - interest rate (IR), money supply (MS), exchange rate (EXR), minimum re-discount rate (MRR), and the Treasury Bill (TB). The real sector variables are treated as endogenous variables while the monetary variables as the exogenous variables. Thus, the econometric estimation period is selected as 1984 - 2010 due to the fact that 1984 was the base year for the computation of most of the monetary and real sector variables.

Hence, the model:

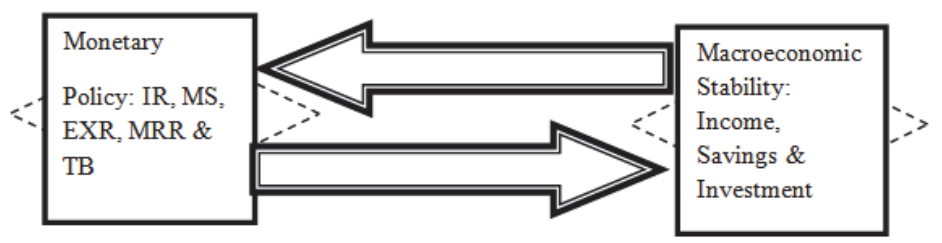

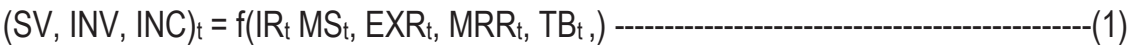

$\mathrm{LNIN}_{\mathrm{t}}=\lambda_{0}+\lambda_{1} \mathrm{LNIR}_{\mathrm{t}}+\lambda_{2} \mathrm{LNMS}_{\mathrm{t}}+\lambda_{3} \mathrm{LNEXR}_{\mathrm{t}}+\lambda_{4} \mathrm{LNMRR}_{\mathrm{t}}+\lambda_{5} \mathrm{LNTB}_{\mathrm{t}}+\mu_{\mathrm{t}}-\mathrm{-}_{-}$

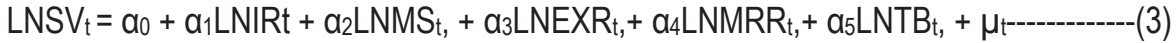

$\mathrm{LNINV}_{\mathrm{t}}=\mathrm{b}_{0}+\mathrm{b}_{1} \mathrm{LNIRt}+\mathrm{b}_{2} \mathrm{LNMS}_{\mathrm{t}}+\mathrm{b}_{3} \mathrm{LNEXR}_{\mathrm{t}}+\mathrm{b}_{4} \mathrm{LNMRR}_{\mathrm{t}},+\mathrm{b}_{5} \mathrm{LNTB}_{\mathrm{t}}+\mu_{\mathrm{t}}-\mathrm{-}^{------(4)}$

Where:

$S V_{t}=$ Savings at time $t$

$\mathrm{INV}_{\mathrm{t}}=$ Investment at time $\mathrm{t}$

$\mathrm{INC}_{\mathrm{t}}=$ Income at time $\mathrm{t}$

$\mathrm{IR}_{\mathrm{t}}=$ Interest Rate at time $\mathrm{t}$

$M S_{t}=$ Money Supply at time $t$

$E X R_{t}=$ Exchange Rate at time $t$

$M R_{\mathrm{t}}=$ Minimum Re-discount Rate at time $\mathrm{t}$

$\mu_{\mathrm{i}}=$ stochastic or random error term (which means properties of zero mean and non-serial correlation)

$a_{i}, b_{i} \& \lambda_{i}=$ coefficients of associated variables

$a_{0}, b_{0} \& \lambda_{0}=$ Constants interception

\section{Results and Discussion}

\subsection{Descriptive Statistics of the Series}

The results of descriptive statistics of the series are presented in Table1 below. The table presents annual descriptive statistics - mean, median, maximum, minimum standard deviation and Jarque-Bera statistic. In summary, Table1 shows that two series; minimum rediscount rate and treasury bill are not normally distributed but all other series satisfied the assumption of normality. This is as shown in the Jarque-Bera result. It is also evidence in the skewness and the kurtosis results to confirm the Jarque-Bera result of test for normality, some of the variables are normally distributed while others are not.

Table 1: Summary of Annual Descriptive Statistics for the Period, 1984-2010

\begin{tabular}{c|cccccccc}
\hline Statistic & EXR & INC & INV & IR & MRR & MS & SV & TB \\
\hline Mean & 71.94256 & 28147362 & 929493.2 & 13.63333 & 13.78444 & 2105647 & 990054.7 & 12.77296 \\
Median & 84.36790 & 14587649 & 247317.9 & 12.21000 & 13.50000 & 429731.3 & 177648.7 & 12.25000 \\
Maximum & 150.0000 & $1.40 E+08$ & 4675862. & 28.02000 & 26.00000 & 12767378 & 6863518. & 26.90000 \\
Minimum & 0.808300 & 205086.0 & 22412.30 & 7.430000 & 6.000000 & 23370.00 & 10988.10 & 6.000000 \\
Std. Dev. & 56.15457 & 37421383 & 1404463. & 5.062522 & 4.125699 & 3491352. & 1806437. & 4.827058 \\
Skewness & -0.094792 & 1.694335 & 1.736920 & 1.172969 & 0.717729 & 1.986552 & 2.225541 & 0.950366 \\
Kurtosis & 1.337097 & 5.075417 & 4.699566 & 3.798120 & 4.249627 & 5.769118 & 6.846448 & 3.953037 \\
Jarque-Bera & 3.151337 & 17.76424 & 16.82560 & 6.907970 & 4.074872 & 26.38526 & 38.93321 & 5.086190 \\
Probability & 0.206869 & 0.000139 & 0.000222 & 0.031619 & 0.130363 & 0.000002 & 0.000000 & 0.078623 \\
Sum & 1942.449 & $7.60 \mathrm{E}+08$ & 25096316 & 368.1000 & 372.1800 & 56852467 & 26731478 & 344.8700 \\
Sum Sq. Dev. & 81986.72 & $3.64 \mathrm{E}+16$ & $5.13 \mathrm{E}+13$ & 666.3574 & 442.5563 & $3.17 \mathrm{E}+14$ & $8.48 \mathrm{E}+13$ & 605.8128 \\
Observations & 27 & 27 & 27 & 27 & 27 & 27 & 27 & 27 \\
\hline
\end{tabular}

Source: E-view Output 
The Figures 1 below, gives the graphical depiction of the patterns of annual trend of the series. The graphs show upward trend movement of all the series except interest rate (IR), minimum rediscount rate (MRR) and treasury bill (TB) do not have specific pattern of trend over a long period of time. Money supply (MS), and others have an upward trend movement over a long period. Variables such as money supply, interest rate, exchange rate, income and savings are still on the rise up to date without any sign of dropping down.
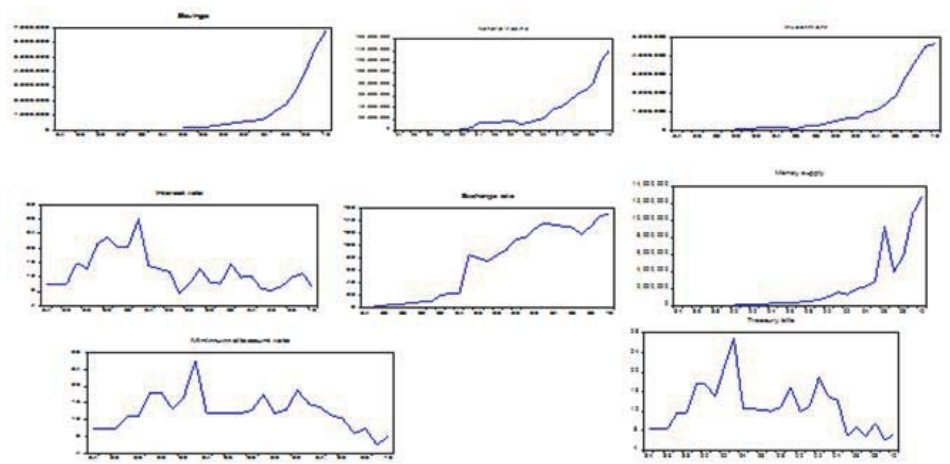

Figure 2: Graphical Descriptive of Series

\subsection{Tests for Model Fit}

The actual fitted and residual values of the endogenous variables employed for the study are to enable us to see whether the variables track both the trend and turning points of the model. Residuals are differences between the one-steppredicted output from the model and the measured output from the validation data set. Thus, residuals represent the portion of the validation data not explained by the model. The top axes show the autocorrelation of residuals for the output. The horizontal scale is the number of lags, which is the time difference (in samples) between the signals at which the correlation is estimated. The horizontal dashed lines on the plot represent the confidence interval of the corresponding estimates. Any fluctuations within the confidence interval are considered to be insignificant. Though, our models have residuals autocorrelation function within the confidence interval, indicating that the residuals are uncorrelated. However, in Figures 2 below showed the actual, fitted and residual values of savings, National income, investment and inflation from monetary policy variables. Similarly, it can be seen that the equations of these variables have good fit since none of them is in the confidence interval of the residual line and all the residual are uncorrelated and pass the independence test. They models have shown evidence that output are formed from the corresponding in input. The implication of this is that the impact of monetary policy input exert on real sector would bring about a corresponding output and would transmit to changes into positive growth of the economy.

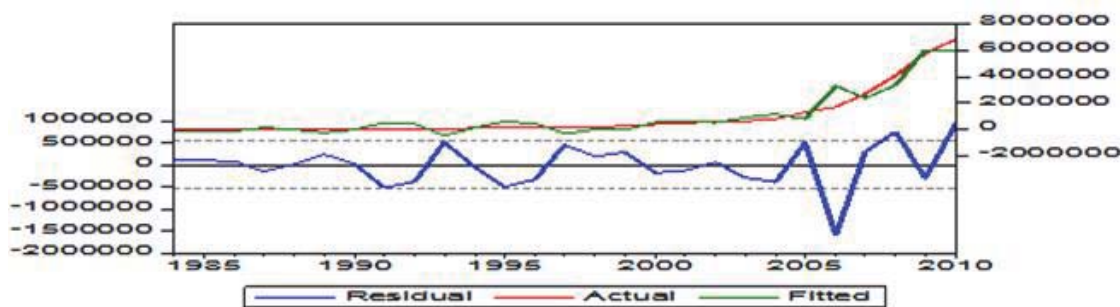

Figure 3a: Actual and Fitted Plots for Model 1: Impact of Monetary Policy on the Real Sector (Savings)

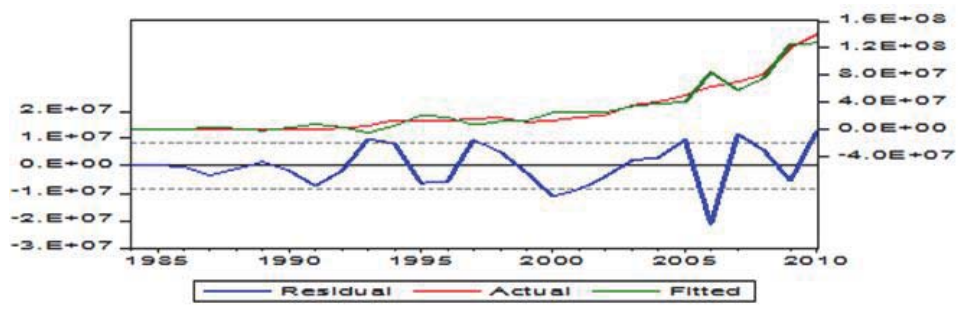

Figure 3b: Actual and Fitted Plots for Model 2: Impact Monetary Policy on the Real Sector (Real Income) 


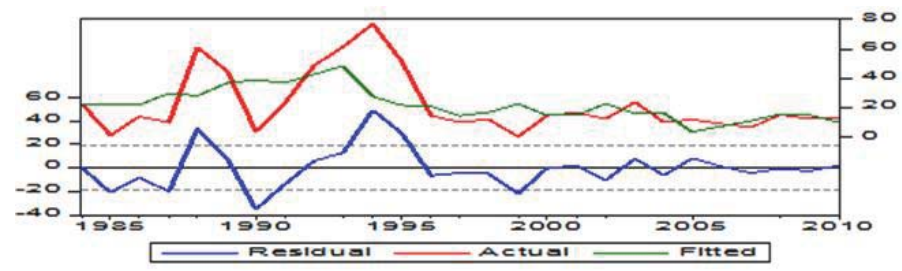

Figure 3c: Actual and Fitted Plots for Model 3: Impact of Monetary Policy on the Real Sector (Investment)

\subsection{Granger Causality Test}

The causality test results suggest a bidirectional causation between the IN and INV. This implies that changes in income may cause to changes in investment and vice versa. Some of the variables suggest unidirectional causality and not vice versa. Some of which are IR, MRR and TB granger cause EXR, but not the other way. This also implies that changes in interest rate, minimum rediscount rate and treasury bill would affect exchange rate but a change in exchange rate does not granger cause changes in interest rate, minimum rediscount rate and treasury bill. In the other words, there is no "reverse causation". Furthermore, there is independence, "no causation" between the IN and EXR, INV and EXR, IR and EXR, MS and EXR as well as , SV and EXR (Table 2). This is a clear indication of the relative positive or negative (as the case may be) impact monetary policy played on the real sector.

Table 2: Granger Causality Test

\begin{tabular}{|c|c|c|c|}
\hline & & & \\
\hline Null Hypothesis: & Obs & F-Statistic & Probability \\
\hline $\begin{array}{l}\text { IN does not Granger Cause EXR } \\
\text { EXR does not Granger Cause INC }\end{array}$ & 25 & $\begin{array}{l}0.07781 \\
0.11460\end{array}$ & $\begin{array}{l}0.92542 \\
0.89231\end{array}$ \\
\hline $\begin{array}{l}\text { INV does not Granger Cause EXR } \\
\text { EXR does not Granger Cause INV }\end{array}$ & 25 & $\begin{array}{l}0.10012 \\
2.16244 \\
\end{array}$ & $\begin{array}{l}0.90518 \\
0.14119 \\
\end{array}$ \\
\hline $\begin{array}{l}\text { IR does not Granger Cause EXR } \\
\text { EXR does not Granger Cause IR }\end{array}$ & 25 & $\begin{array}{l}3.68739 \\
2.99974 \\
\end{array}$ & $\begin{array}{l}0.04333 \\
0.07255 \\
\end{array}$ \\
\hline $\begin{array}{l}\text { MRR does not Granger Cause EXR } \\
\text { EXR does not Granger Cause MRR }\end{array}$ & 25 & $\begin{array}{l}5.44681 \\
1.24374 \\
\end{array}$ & $\begin{array}{l}0.01293 \\
0.30966 \\
\end{array}$ \\
\hline $\begin{array}{l}\text { MS does not Granger Cause EXR } \\
\text { EXR does not Granger Cause MS } \\
\end{array}$ & 25 & $\begin{array}{l}0.38002 \\
0.58495 \\
\end{array}$ & $\begin{array}{l}0.68868 \\
0.56639 \\
\end{array}$ \\
\hline $\begin{array}{l}\text { RESID does not Granger Cause EXR } \\
\text { EXR does not Granger Cause RESID }\end{array}$ & 23 & $\begin{array}{l}4.18553 \\
0.92890 \\
\end{array}$ & $\begin{array}{l}0.03216 \\
0.41312 \\
\end{array}$ \\
\hline $\begin{array}{l}\text { SV does not Granger Cause EXR } \\
\text { EXR does not Granger Cause SV } \\
\end{array}$ & 25 & $\begin{array}{l}0.41174 \\
2.67995 \\
\end{array}$ & $\begin{array}{l}0.66798 \\
0.09307 \\
\end{array}$ \\
\hline $\begin{array}{l}\text { TB does not Granger Cause EXR } \\
\text { EXR does not Granger Cause TB } \\
\end{array}$ & 25 & $\begin{array}{l}4.60194 \\
1.53756 \\
\end{array}$ & $\begin{array}{l}0.02269 \\
0.23925 \\
\end{array}$ \\
\hline $\begin{array}{l}\text { INV does not Granger Cause INC } \\
\text { IN does not Granger Cause INV }\end{array}$ & 25 & $\begin{array}{l}7.61523 \\
8.46584 \\
\end{array}$ & $\begin{array}{l}0.00348 \\
0.00217 \\
\end{array}$ \\
\hline $\begin{array}{l}\text { IR does not Granger Cause INC } \\
\text { IN does not Granger Cause IR }\end{array}$ & 25 & $\begin{array}{l}2.04646 \\
1.15225 \\
\end{array}$ & $\begin{array}{l}0.15538 \\
0.33603 \\
\end{array}$ \\
\hline
\end{tabular}

\subsection{Results of the Vector Autoregressive Model (VAR)}

For ease of analysis, the relevant portions have been extracted from the reported results of VAR output. We therefore concentrate on interpreting only relevant results for models. The summary results are shown in Table 3 indicated first and second models interest rate and exchange rate carried negative coefficients, other variables in the models carried positive coefficients. While the third model, exchange rate and minimum rediscount rate carried positive signs. This implies that money supply has a positive significant influence on real sector variables. Other variables have weak positive or negative influence on both savings, investment or real income. It is shown that among all the exogenous variables, only money supply that has positive relationship with savings, investment and real income. This implies that money supply can be used as a determining fact in the real sector of Nigerian economy. In the other hand, the R-squared of all the models are over 0.9212 . This shows that over $92 \%$ of variations in the real sector are caused by variation in monetary 
policy variables.

The hypothesis states that monetary policy variables have no significant effect on real sector of the Nigerian economy. Variations in monetary policy variables seem to have a poor effect on the real sector. Only money supply and minimum rediscount rate seem to have any significant impact on the real sector variable, investment. Based on this result (Table 3), we can conclude that though we have rejected the null hypothesis which states that, monetary policy does not have any significant effect on real sector variable, it is obvious that a very weak impact was suggested by the data.

Table 3: Summary Results of VAR test of impact of monetary policy variables on the real sector

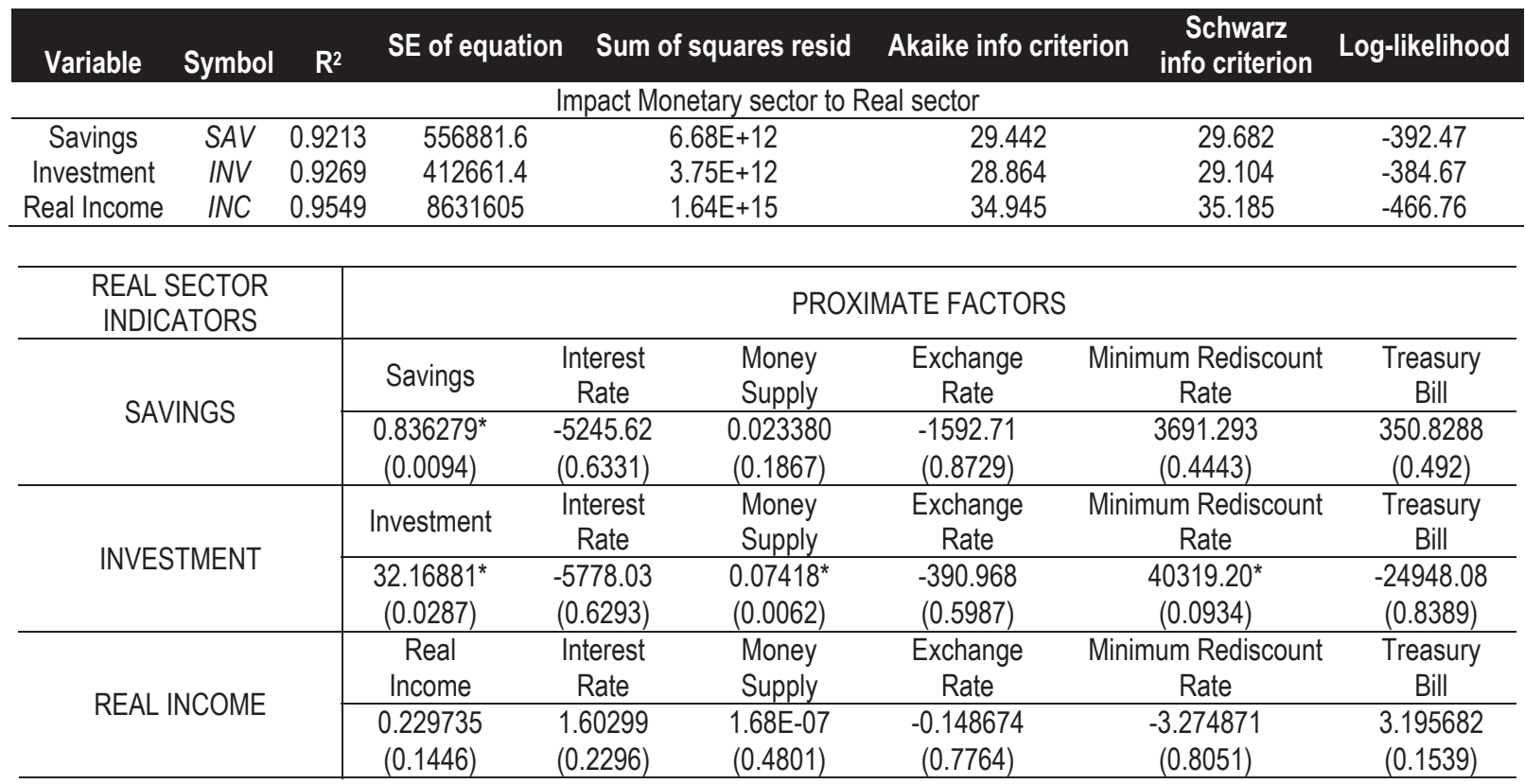

( ) - prob-value, ${ }^{*}$ significant at 5 per cent level

\subsection{Impulse Response of Real Sector to Money Supply}

To examine further the short- run dynamic properties of monetary policy, we employ the forecast error cholesky one standard deviation (S. D.) impulse response analysis. By definition, the cholesky one S. D. shows the proportion of forecast error variance for each variable that is attributable to its own innovation and to innovation in the other endogenous variables. This method provides complementary information on the dynamic behaviour of the variables in the system. It is possible to decompose the forecast variance into the contributions by each of the different shocks.

From the above results, money supply shows a significant effect on real sector, therefore, for the sake of accuracy and precision, is necessary to examine the shot-run dynamics properties of monetary policy through money supply to real sector. The response of real sector variables to monetary policy variables tightening is presented in Figure 4. Initially, savings shocks from money supply started on a negative note at the first period but converted to positive horizon at period two and continued on positive plane all through to the end of the time horizon. The implication of this is that more money in circulation could lead to more savings in the economy and when monetary policy through money supply is tightening, this reduces money in circulation and hence low savings. This result is in line with Osuagwu, 2009 and Okpara, 2009. Among others, shocks on investment from money supply commence on a positive note from the origin and rise to peak at period three and slightly decrease insignificantly on the positive plane and continued to the end of time horizon. In that case it would imply that real sector variables in Nigeria responds to expected money supply. In all cases however the magnitude seems to be small and not significant as with the response of the output. In conclusion, the magnitudes of the responses of real sector to money supply shocks are small, but seem to be similar in speed and direction. 

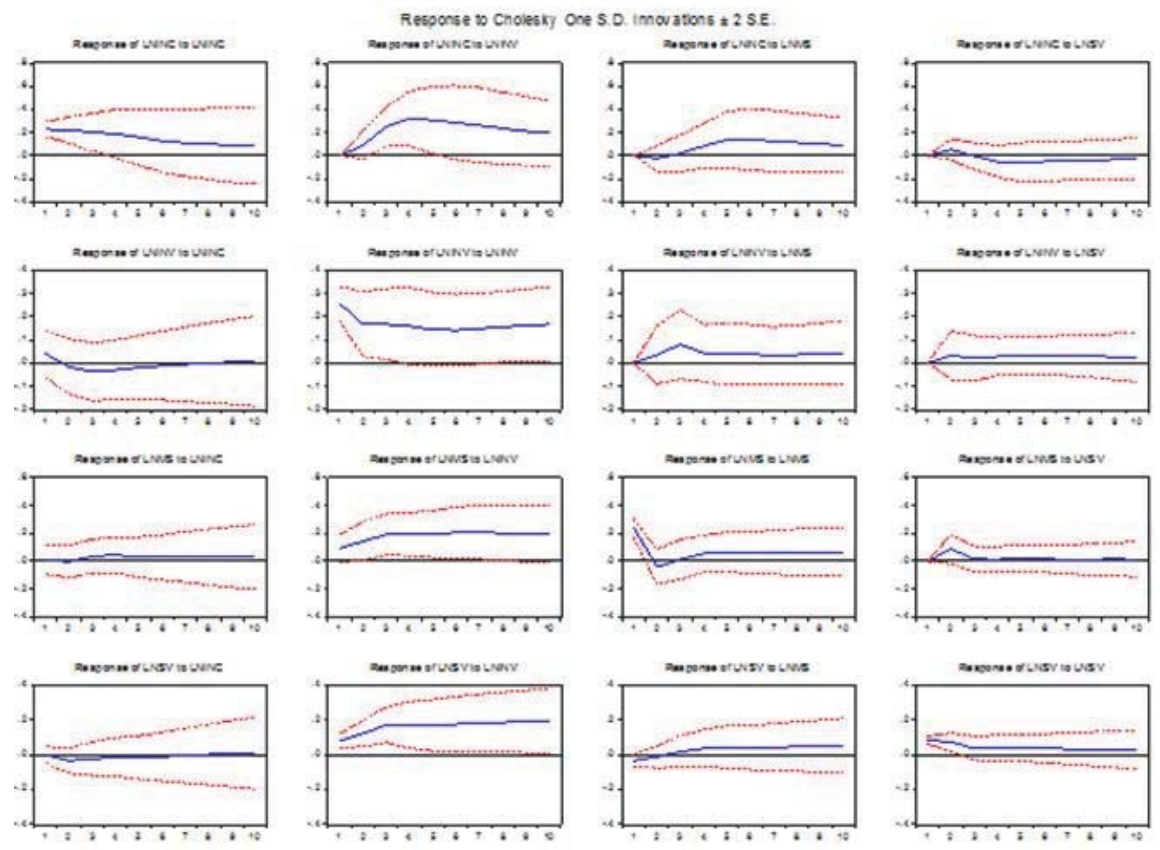

Figure 4: Impulse Response of Real Sector to Money Supply

\section{Conclusion and Recommendation}

Monetary policy plays a significant role in the operation of economies. Differences in transmission mechanisms can generate asymmetric behaviour between monetary policy and real sector. The paper explores the significance of the monetary policy channels using VAR model, as tests suggest the null of no cointegration cannot be rejected based on the variables used. A significant finding is that the effect of a monetary policy contraction on real sector seems to significant through money supply on savings, income and investment. However, the magnitude of the impact seems, in all cases, not to be significant at the 5 per cent level (two standard errors). The effect of monetary policy contraction through money supply has positive influence on all the three variables, namely; savings, real income and investment. Interest rate has a negative impact on both savings and investment but has positive effect on income. Among other variables, Minimum rediscount also has positive impact on both savings and investment and negative coefficient on income.

The main implication to be drawn from these results then seems to be that the money supply channel is important as a means to improve real sector economy in Nigeria. However, on the other hand, it is likely that the main channel of money supply is the bank lending channel as suggested by literature for the country with undeveloped financial markets. There is need for further research to establish the pattern of the bank lending channel for the country. Therefore, The Central Bank of Nigeria intensify effort in controlling liquidity in circular and sensitise the public on the activities of money market actors.

\section{References}

Ando, A., and F. Modigliani (1963), The 'life cycle' hypothesis of saving: aggregate implications and tests. American Economic Review, 53 (1), 55-84.

Aysan, A., Gaobo P. and Marie-Ange V., (2005), How to Boost Private Investment in the MENA Countries: The Role of Economic Reforms, Topics in Middle Eastern and North African Economies, MEEA, Online Journal, pp. 1-15.

Bernanke, B. and Gertler M. (2001), Should Central Banks Respond to Movements in Asset Prices, American Economic Review Papers and Proceedings, Vol. 91.

Blejer, M. I. and Mohsin S. K., (1984), Government Policy and Private Investment in Developing Countries, IMF Staff Papers, Vol. 31, pp. 379-403.

Boughrara, A., (2009), Monetary Policy Transmission Mechanisms in Morocco and Tunisia, Economic Research Forum Working Paper No. 460, April, Tunis.

Ender, W. (1995), Applied Econometric Time Series, New York, John Wiley.

Fischer, S., (1998). Capital Account Liberalization and the Role of the IMF, Princeton Essays in International Finance 207, pp. 1-10.

Fry, M. J., (1978), Money and Capital or Financial Deepening in Economic Development? Journal of Money, Credit, and Banking, Vol. 
10, pp. 464-475.

Funke, N., (2002), Stock Market Developments and Private Consumer Spending in Emerging Markets, IMF Working Paper 02/238.

Gertler, M., and Gilchrist, S., (1993), The Role of Credit Market Imperfections in the Monetary Transmission Mechanism: Arguments and Evidence, Scandinavian Journal of Economics, 95.

Granville, B., Mallick, S., (2009), Monetary and Financial Stability in the Euro area: Procyclicality Versus Trade- off, Journal of International Financial Markets, Institutions Vol.6 No.3

Gujirati, D.N. and Porter, D.C. (2009). Basic Econometrics (5th Ed.). Boston: McGraw Hill.

Gurley, J.G. and Shaw, E.S. (1967), Financial Structure and Economic Development in Economic Development and Cultural Change, 15 3,(April), pp. 257-268.

Heinrich, B. (2010), The real and the Financial Sector of a Monetary Production Economy in the Perspective of Classical-Keynesian Political Economy. VII International Colloquim on Getting out of the Current Economic Crisis in the Light of Altenative

Henry, P. B. (2000), Do Stock Market Liberalization Cause Investment Booms? Journal of Financial Economics, Vol. 58, pp. 301-334.

Jansen, D., Tsai, C. (2010), Monetary policy and stock returns: Financing constraints and Asymmetries in Bull and Bear Markets, Journal of Empirical Finance, Vol. 17.

Jardak, T. and Ewa W., (2009), The Monetary Transmission Mechanism in Tunisia: Recent Developments, Banque Centrale de Tunisie, unpublished manuscript.

Okpara G. C. (2009). Capital Market and the Development of Nigerian Economy, Nigeria Economic .Financial Review, 1(1) March.

Osuagwu, E. S. (2009), The impact of Monetary policy variables on the performance of the stock market, Nigerian Journal of Securities and finance, Vol. 14, No. 2, pp. 17-39.

Ovidiu S. Delia-Elena, D. and Anca, E. N., (2012), The Impact of Monetary Policy on Stock Prices in Eastern European Markets, Department of Business Administration "Alexandru Ioan Cuza" University of lasi Carol I Bd., no. 11, 700505 ROMANIA

McDonald, D., (1983), The Determinants of Saving Behavior in Latin America, (unpublished; Washington: International Monetary Fund).

Mishra, P., Peter J. M. and Antonio S., (2010), Monetary Transmission in Low Income Countries, IMF Working Paper WP/10/223, October, International Monetary Fund, Washington, D.C.

Misati, R. N. and Esman M. N., (2010), Financial Development and Private Investment in Sub-Saharan Africa, Journal of Economics and Business.1

Misati, R. N., (2007), Liberalization, Stock Market Development and Investment Efficiency in Africa, International Review of Business Research Papers, Vol. 3, pp. 183-191.

Modigliani, F., and Tarantelli E. (1975). The consumption function in a developing economy and the Italian experience. American Economic Review, 65 (5), 825-842.

Development Paradigms, Organised by the Department of Economics, University of Brasila

Mukherjee, Tarun K. and Naka Atsuyuki (1995), Dynamic Relations Between

Macroeconomic Variables and the Japanese Stock Market: An Application of Vector Error Correction Model," The Journal of Financial Research, XVIII. (2), 223-237.

Naceur, S. B., Samir G. and Omran M., (2008), Does Stock Market Liberalization Spur Financial and Economic Development in the MENA Region? Journal of Comparative Economics, Vol. 36, pp. 673-693.

Neaime, S., (2008), Monetary Policy Transmission and Targeting Mechanisms in the MENA region, Economic Research Forum Working Paper No. 395, April, Beirut.

Nelson, C. R. (1976). Inflation and rates of return on common Stocks, Journal of Finance 31, No.2, (May): pp. 471-483.

Nelson, E., (2000), UK Monetary Policy 1972-1997: A Guide Using Taylor Rules, Bank of England Working Paper 120.

Reinhart, C. M. and Jonathan O., (1995), Saving and Real Interest Rates in

Developing Countries, University Library of Munich, Germany, MPRA Paper Number 13352.

Rogoff, K. (1999). International Institutions for Reducing Global Financial Instability,, Journal of Economic Perspectives, Vol. 13(4), pp. 21-42.

Roosa, R.V. (1951), Interest rates and the central bank. In Money, Trade, and Economic Growth: Essays in Honor of John Henry Williams. New York: Macmillan.

Ross, S.A., Westerfield, R.W. and Jordan, B.D., (1995), Fundamentals of Corporate Finance.3rd Edition. Chicago, Illinois: Rirchard Irwin Inc..

Serven, L., (2003), Real-Exchange-Rate Uncertainty and Private Investment in LDCS, The Review of Economics and Statistics, Vol. 85, pp. 212-218.

Summers, L. (2000), International Financial Crises: Causes, Prevention, and Cures, American Economic Review, Vol. 90, pp. 1-16.

Sundararajan, V. and Subhash T. (1980), Public investment, crowding-out and growth: A dynamic model applied to India and Korea, IMF Staff Papers, Vol. 27, pp. 814-855.

Tobin, J. (1969). A general equilibrium approach to monetary theory. Journal of Money, Credit, and Banking, 1 (1), 15-29.

Trew G. R.,(2006), Financial Stability and Monetary Policy - A Framework, CESifo Working Paper Series No. 121

Tun, W. U. And Hugh, T.P., (1973), Stock and Bond Issue and Capital Markets in Less Developed Countries, IMF Staff Papers Vol. 20 No. 2 pp 253-317. 